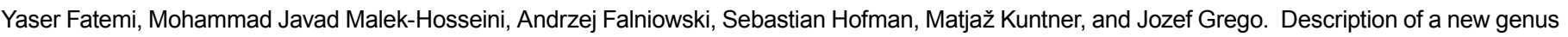
and species as the first gastropod species from caves in Iran. Journal of Cave and Karst Studies, v. 81, no. 4, p. 233-243. DOI:10.4311/2019LSC0105

\title{
DESCRIPTION OF A NEW GENUS AND SPECIES AS THE FIRST GASTROPOD SPECIES FROM CAVES IN IRAN
}

\author{
Yaser Fatemi', Mohammad Javad Malek-Hosseini ${ }^{2,3,4}$, Andrzej Falniowski ${ }^{5}$, Sebastian Hofman ${ }^{6}$, \\ Matjaž Kuntner ${ }^{2,3}$, Jozef Grego,c
}

ABSTRACT

We report on a new stygobiont truncatelloid gastropod from the sulfidic ponds of Tashan Cave in the Zagros Mountains of Southwest Iran. The hydrogen sulfide habitat resembles those hitherto known for gastropods from sulfide-rich caves in Romania, Italy and Greece. The newly described genus Trogloiranica n. gen. with a newly described T. tashanica $\mathrm{n}$. sp represent the first true stygobiont gastropods found in Iran. The phylogeny inferred from the mitochondrial (cytochrome oxidase subunit I) and the nuclear (histone 3) genomes, as well as anatomical evidence, place T. tashanica in the family Moitessieriidae Bourguignat, 1863. The new genus may represent an evolutionary relict from the post Miocene before the split of the families Moitessieriidae and Cochliopidae Tryon, 1866.

\section{INTRODUCTION}

The freshwater Mollusca of Iran have been a focus of research during past two decades (Mansoorian, 2001; Glöer and Pešić, 2009, 2012; Moghadam and Chegini, 2009; Mowlavi et al., 2009; Shahabuddin et al., 2012; Ektefa et al., 2013; Nouroozi, 2014), and the taxonomic position of the local Ponto-Caspian Hydrobiidae has been clarified only recently (Dellicado et al., 2016). Iran is situated at the interface of three zoo-geographic realms, Palaearctic, Oriental (Indo-Malayan), and Afrotropical (Ethiopian). The karstifiable carbonate formations cover around $11 \%$ of Iran's surface area with more than half (55.2\%) being located at the Zagros Mountains in western Iran (Raeisi and Laumanns, 2012). Thus, it is not surprising that more than $90 \%$ of known Iranian troglobiont taxa are found in the Zagros karst formations (Malek-Hosseini and Zamani, 2017).

Tashan Cave, located near the Sarjooshar Village, harbors a unique ecosystem. The recent discovery of a blind fish, Garra tashanensis Mousavi-Sabet, Vatandoust, Fatemi and Eagderi, 2016, and of the isopod Stenasellus tashanicus Khalaji-Pirbalouty, Fatemi, Malek-Hosseini, Kuntner, 2018, has been followed by other discoveries including the new gastropod genus and species reported here. The Tashan Cave represents a specific hypogean habitat with several cave ponds containing groundwater rich in hydrogen sulfide. Earlier studies performed in sulfide-rich caves by Hose et al. (2000); Engel (2012); and Jones et al. (2014) have shown that chemoautotrophic sulfur-oxidizing microorganisms thrive in such environments using the redox interface between the sulfide in the water and the oxygen in the atmosphere to produce food in situ, independent of the external light energy. Sulfuric acid is a product of the bacterial sulfur oxidation and accelerates the dissolution of the limestone bedrock in the process called sulfuric acid speleogenesis (SAS), which results in the formation of sulfide caves (Engel et al., 2004; Porter et al., 2009). It is estimated that hydrogen sulfide-rich phreatic waters and microbially-generated sulfuric acid were involved in the speleogenesis of around $10 \%$ of worldwide known caves (Palmer, 2007). However, only a few of these caves remain active ducts containing hydrogen sulfide-rich groundwater. The sulfide caves host interesting ecosystems with unusually rich and diverse invertebrate communities dominated by crustaceans (Peterson et al., 2013; Por, 2014), insects (Tobler et al., 2013) and occasionally fishes (Reisch et al., 2010; Roach et al., 2011; Mousavi-Sabet at al., 2016). While sulfide-based ecosystems are usually well-recognized inside deep sea trenches (Deming and Baross, 1993), the groundwater sulfide ecosystems remain poorly studied (Engel, 2007). The sulfide cave ecosystems received attention with the studies of Sarbu et al. (1996). The first studied cave containing a sulfide ecosystem was Movile Cave in Romania (Sarbu and Popa, 1992; Sarbu et al., 1996; Sarbu, 2000; Engel, 2012), followed by the Frasassi caves and Grotto Azzurra in Italy (Macalady et al., 2007; Peterson et al., 2013), Tito Bustillo and Maltravieso caves in Spain (Schabereiter-Gurtner, 2002; Arrozo et al., 1997), Fiume Coperto Cave in Italy (Latella et al., 1999), Melissotrypa Cave in Greece (Falniowski and Sarbu, 2015), El Hamma in Tunisia (Por, 1963), Ayalon Cave and the Tabgha Spring in Israel (Por, 1963; 2007; 2011), Kugitangtou caves in Turkmenistan (Maltsev and Korshunov, 1998), Cueva de Villa Luz in Mexico (Hose et al., 2000; Engel, 2007), Bungonia and Nullarbor caves with Bunder Sinkhole in Australia (Holmes et al., 2001; Jaume et al., 2001), Lower Kane

\footnotetext{
${ }^{1}$ Young Researchers and Elite Club, Bandar Abbas Branch, Islamic Azad University, Bandar Abbas, Iran

2 Evolutionary Zoology Laboratory, Department of Organisms and Ecosystems Research, National Institute of Biology, Ljubljana, Slovenia

${ }^{3}$ Evolutionary Zoology Laboratory, Biological Institute ZRC SAZU, Ljubljana, Slovenia

${ }^{4}$ Department of Biology, Biotechnical Faculty, University of Ljubljana, Ljubljana, Slovenia

${ }^{5}$ Department of Malacology, Institute of Zoology and Biomedical Research, Jagiellonian University, Krakow, Poland

${ }^{6}$ Department of Comparative Anatomy, Institute of Zoology and Biomedical Research, Jagiellonian University, Krakow, Poland

${ }^{7}$ Horná Mičiná, SK-97401 Banská Bystrica, Slovakia

c Corresponding author: jozef.grego@gmail.com
} 
Cave in Wyoming, USA (Porter et al., 2002), Cesspool Cave in Virginia, USA (Engel et al., 2001), and the Mammoth and Parker Caves in North America (Hutchins et al., 2016).

Hydrogen sulfide is toxic for most organisms (Kelley et al., 2006), and only five of the around twenty so far known sulfide cave ecosystem sites host stygobiont gastropod species, as likely outcomes of extreme sulfide adaptation: $\mathrm{He}$ leobia dobrogica (Grossu and Negrea, 1989) from Movile Cave (Falniowski et al., 2008), Islamia sulfurea Bodon and Cianfanelli, 2012 from the Frasassi caves (Bodon et al., 2009; Bodon and Cianfaneli, 2012), Physella spelunca Turner and Clench, 1974 from Lower Kane Cave in Wyoming (Porter, 2002; Wethington and Guralnick, 2004) as well as Iglica hellenica and Daphiola magdalenae (Falniowski and Sarbu, 2015) from Melissotrypa Cave in Greece. The discovery of a sixth sulfidic stygobiont gastropod species in the Tashan Cave of Iran, reported here, is thus of general ecological importance.

\section{MATERIAL AND METHODS}

Snails were collected from pools in Tashan Cave, located under a limestone plateau close to Sarjooshar Village in the south-eastern part of the Zagros Mountains, Tashan district, Behbahan County, Khuzestan Province, southwest Iran (Fig. 1 and 2). Specimens were collected by using dropper pipettes and forceps and preserved in $96 \%$ ethanol. A few specimens were transferred into a small rimstone basin at the cave pool shelf for photographing and subsequently returned to the pool.

The sampled snails were fixed in $80 \%$ ethanol. The dissections were done under a NIKON SMZ18 microscope with dark field, and the structures were photographed with a CANON EOS 50D digital camera. Frontal, ventral, and lateral images of the holotype were made using a Nikon SMZ25 microscope with a Nikon D200 camera and an AF-S Micro NIKKOR 60 mm lens at the Vienna Natural History Museum (NHMW), Austria. Morphological terms follow Hershler and Ponder (1998).

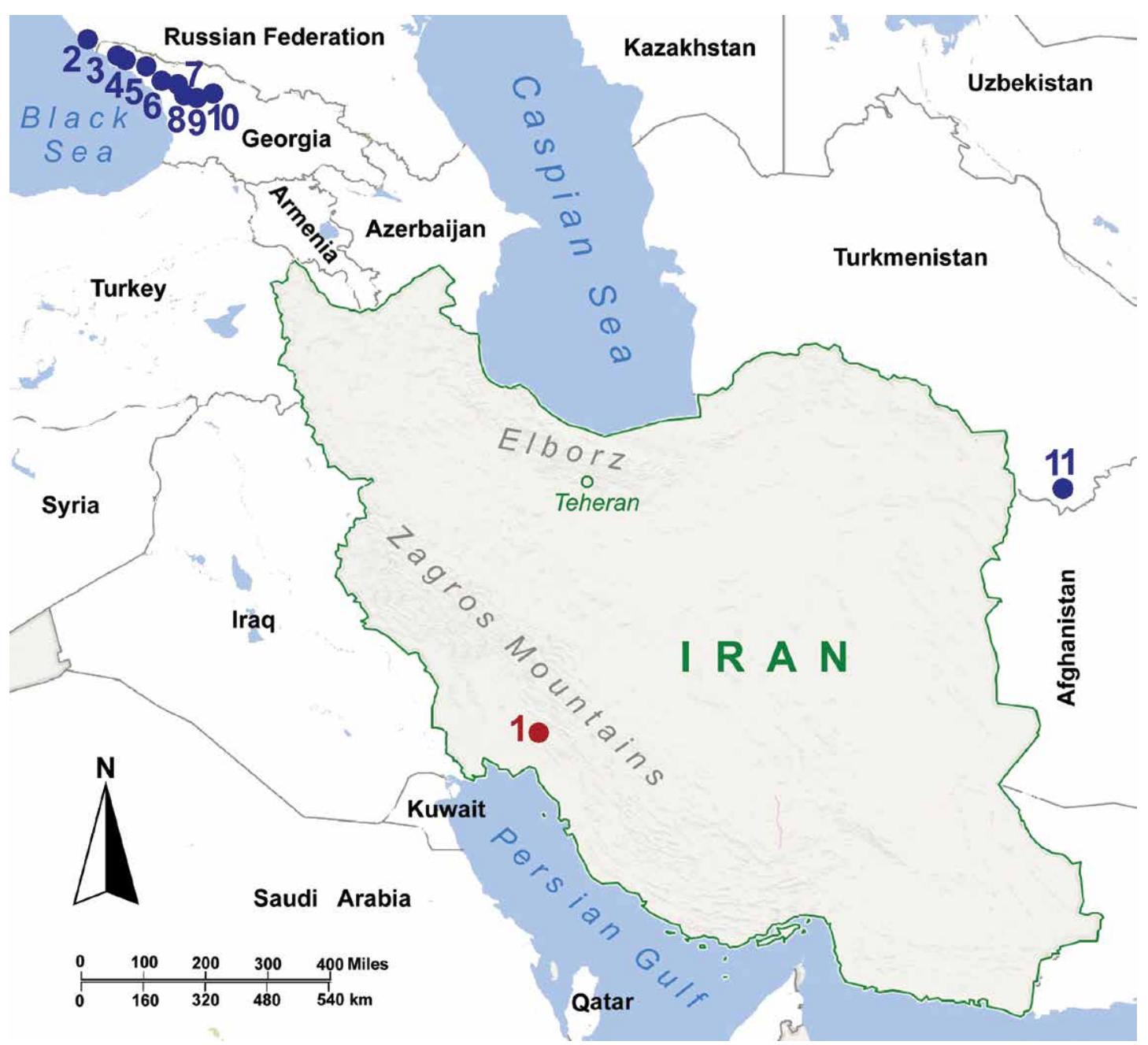

Figure 1. Map of Iran with the type locality of Trogloiranica tashanica n. sp.: Khuzestan Province, Behbahan County, Tashan district, Sarjooshar Village, Tashan Cave (1 - Red ring) and geographically closest records of stygobiont gastropod species from SW Caucasus (2-10 - Blue dots) and from Turkmenistan, Kushka, Shar-Arab spring (11 - Blue dot).
DNA was extracted from foot tissue, hydrated in Tris-EDTA (TE) buffer, using a Sherlock extraction kit (A\&A Biotechnology), and dissolved in $20 \mathrm{~mL}$ of TE buffer. The extracted DNA was stored at $-80{ }^{\circ} \mathrm{C}$ at the Department of Malacology of Institute of Zoology and Biomedical Research of the Jagiellonian University in Kraków. Our study targeted nucleotide data from the mitochondrial (cytochrome oxidase subunit I - COI) and the nuclear (histone $3-\mathrm{H} 3$ ) genomes, to produce phylogenetic inference from individual and combined gene datasets. Details of PCR conditions, primers used, and sequencing methods follow Szarowska et al. (2016). Sequences were aligned by MUSCLE (Edgar, 2004) implemented in MEGA 6 


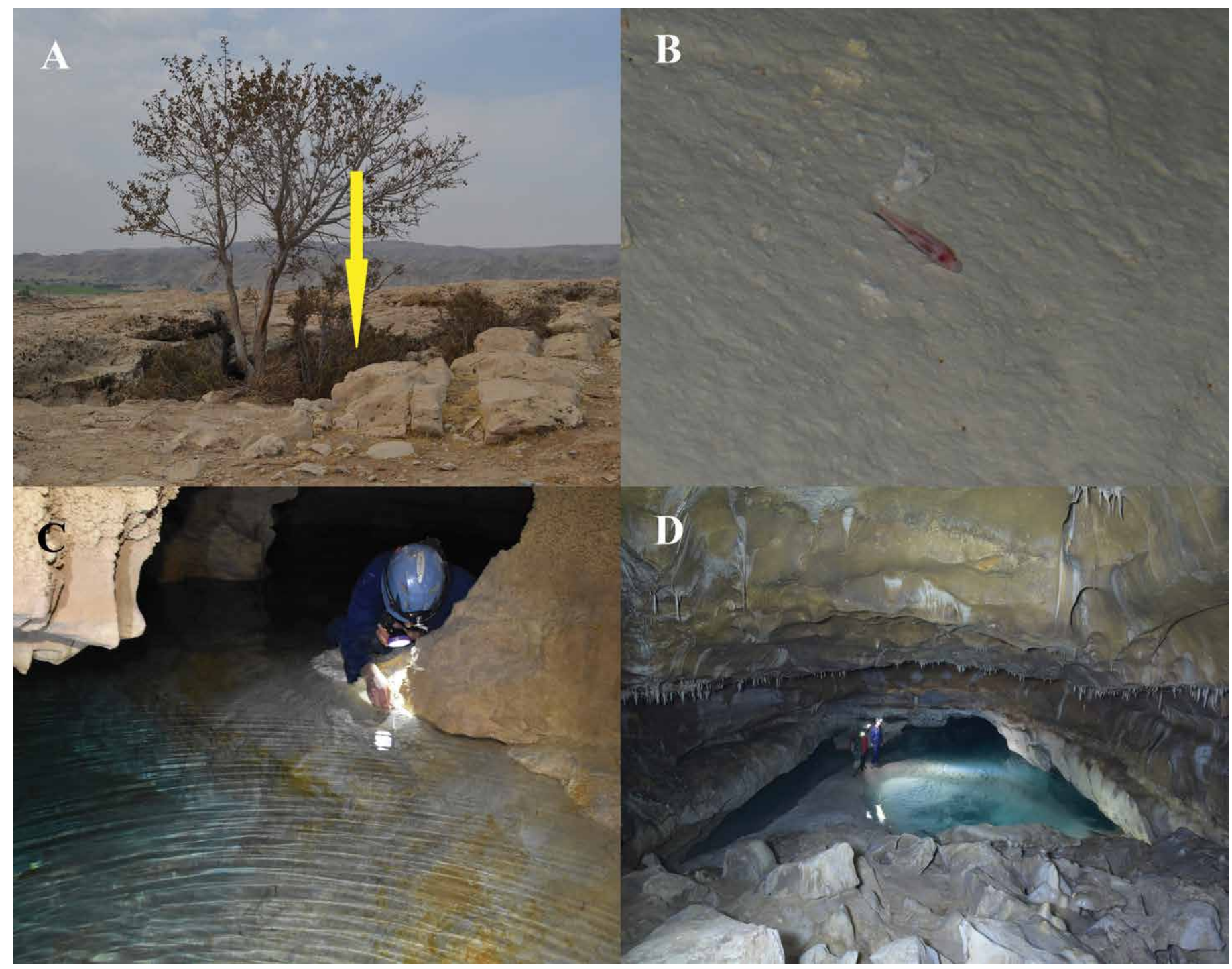

Figure 2. Photos of the type locality of Trogloiranica tashanica n. sp.: A: Tashan Cave entrance on the semi-desert limestone plateau; B hydrogen sulfide-rich pond inside the Tashan cave showing Garra tashanensis; C and D: sampling at the type locality (photo: Mohammad Javad Malek-Hosseini and Yaser Fatemi).

(Tamura et al., 2013) and in Bioedit 7.1.3.0 (Hall, 1999). The saturation test (Xia, 2000, Xia et al., 2003) was performed using DAMBE (Xia, 2013). Additional sequences from GenBank were used in the phylogenetic analysis (Table S1). The phylogenies were inferred using Bayesian inference $(\mathrm{BI})$ and maximum likelihood $(\mathrm{ML})$.

The Bayesian analyses were run using MrBayes v. 3.2.3 (Ronquist et al., 2012) with the default priors. Two simultaneous analyses were performed, each of which lasted 10,000,000 generations, with one cold chain and three heated chains, starting from random trees and sampling the trees every 1,000 generations. The first $25 \%$ of trees were discarded as burn-in. The analyses were summarized as a $50 \%$ majority-rule tree. The ML approach was applied with RAxML v. 8.0.24 (Stamatakis, 2014). We applied the GTR model, whose parameters were estimated by the RaxML (Stamatakis, 2014). One thousand searches were initiated with starting trees obtained through the randomized stepwise addition maximum parsimony method. The tree with the highest likelihood score was considered as the best representation of the phylogeny. Bootstrap support was calculated with 1,000 replicates and summarized on the best $\mathrm{ML}$ tree. RAxML analyses were done in CIPRES Science Gateway (Miller et al., 2010).

\section{Abbreviations}

NMBE

NHMUK

NHMW

ZMUH
Naturhistorisches Museum, Bern, Switzerland

Natural History Museum, London, UK

Natural History Museum, Vienna, Austria

Zoological Museum, University of Hormozgan, Iran 


$\begin{array}{ll}\text { SMF } & \text { Senckenberg Museum, Frankfurt, Germany } \\ \text { H } & \text { Shell height } \\ \text { W } & \text { Shell width } \\ \text { BH } & \text { Height of the body whorl } \\ \text { BW } & \text { Width of the body whorl } \\ \text { AH } & \text { Aperture height } \\ \text { AW } & \text { Aperture width } \\ \text { LT } & \text { Type locality }\end{array}$

\section{RESULTS}

The molecular and anatomical investigation of the live gastropods from the type locality in Tashan Cave revealed it to be a new species belonging to a new genus in Moitessieriidae Bourguignat, 1863.

\section{Superfamily Truncatelloidea Gray, 1840 \\ Family Moitessieriidae Bourguignat, 1863 \\ Genus Trogloiranica n. gen. \\ Diagnosis}

The diagnostic features of the genus are the same as those of the type species, Trogloiranica tashanica n. sp. The oval shell shape with low spire is unique within the Moitessieriidae. Nevertheless, similar shell shapes seem to have convergently evolved in other truncatelloid families such as Hydrobiidae Stimpson, 1865, Cochliopidae Tryon, 1866, Pomatiopsidae Stimpson, 1865, and Tateidae Sacco, 1896.

\section{Etymology}

The name derives from a prefix troglo- referring to the cave habitat of the new taxon and suffix -iranica referring to the country of origin.

\section{Trogloiranica tashanica sp. $\mathrm{n}$.}

\section{Type locality}

Iran, Khuzestan Province, Behbahan County, Tashan district, Sarjooshar Village, sulfidic freshwater ponds inside Tashan Cave, $30^{\circ} 51^{\prime} 54 " \mathrm{~N} ; 50^{\circ} 10^{\prime} 29 " \mathrm{E}$ (altitude $559 \mathrm{~m}$ a.s.I.).

\section{Type material}

Holotype: type locality: Yaser Fatemi and Mohammad Javad Malek-Hosseini leg. August 23, 2017 (holotype NMBE 558282).

Paratypes: type locality (same data) one paratype NMBE 558283; one paratype in each lot of ZMUH 123, 124 and 125; SMF 358125 one specimen, four specimens in coll. Grego; type locality Yaser Fatemi and Mohammad Javad Malek-Hosseini leg. August 27, 2017, two specimens in coll. Malek-Hosseini; type locality (same data); Yaser Fatemi and Mohammad Javad Malek-Hosseini leg. 17. March 2018 coll. 10 specimens in coll. Malek-Hosseini, two in coll. Jagiellonian University, Krakow.

\section{Measurements}

Holotype: H 2.39 mm; W 1.69 mm; BH 1.73 mm; NW 1.14; AH 1.69, AW 0.86 (holotype). Figure 3, A1-A6.

\section{Diagnosis}

The low spire with oval shell shape of the new species is rather unusual within the family Moitessieriidae, but a similar shape with more elevated spire is present in Bythiospeum lamperti (Geyer, 1907). Similar shell morphology can be found in representatives of other truncatelloid families such as: Pseudamnicola hauffeni Delicado and Ramos, 2012, Hydrobiidae from Spain; Aroapyrgus pasionensis Goodrich \& Van der Schalie, 1937, Cochliopidae from Guatemala; Tricula spelaea Grego, 2018, Pomatiopsidae from Laos; Pseudotricula auriforma Ponder, Clark, Eberhard and Studer, 2005, Tateidae from Tasmania, and in the hydrobiid Turkmenamnicola lindholmi (Zhadin, 1952) from Turkmenistan. The cochliopid Heleobia dobrogica (Grossu \& Negrea, 1989) found in similar sulfidic habitats in Movile Cave, Romania, has much more elongate shell shape. However, the molecular and anatomical data distinguish the new species from all other morphologically convergent species.

\section{Description}

Oval shell with conical spire with four rounded slightly convex whorls with a semi-deep suture and a blunt apex. Shell surface smooth with faint transverse growth lines covered by horny yellowish periostracum and partly by precipitated reddish-brown mineral crystals especially at the suture and marginal part of the body whorl. Aperture elongate-oval, 

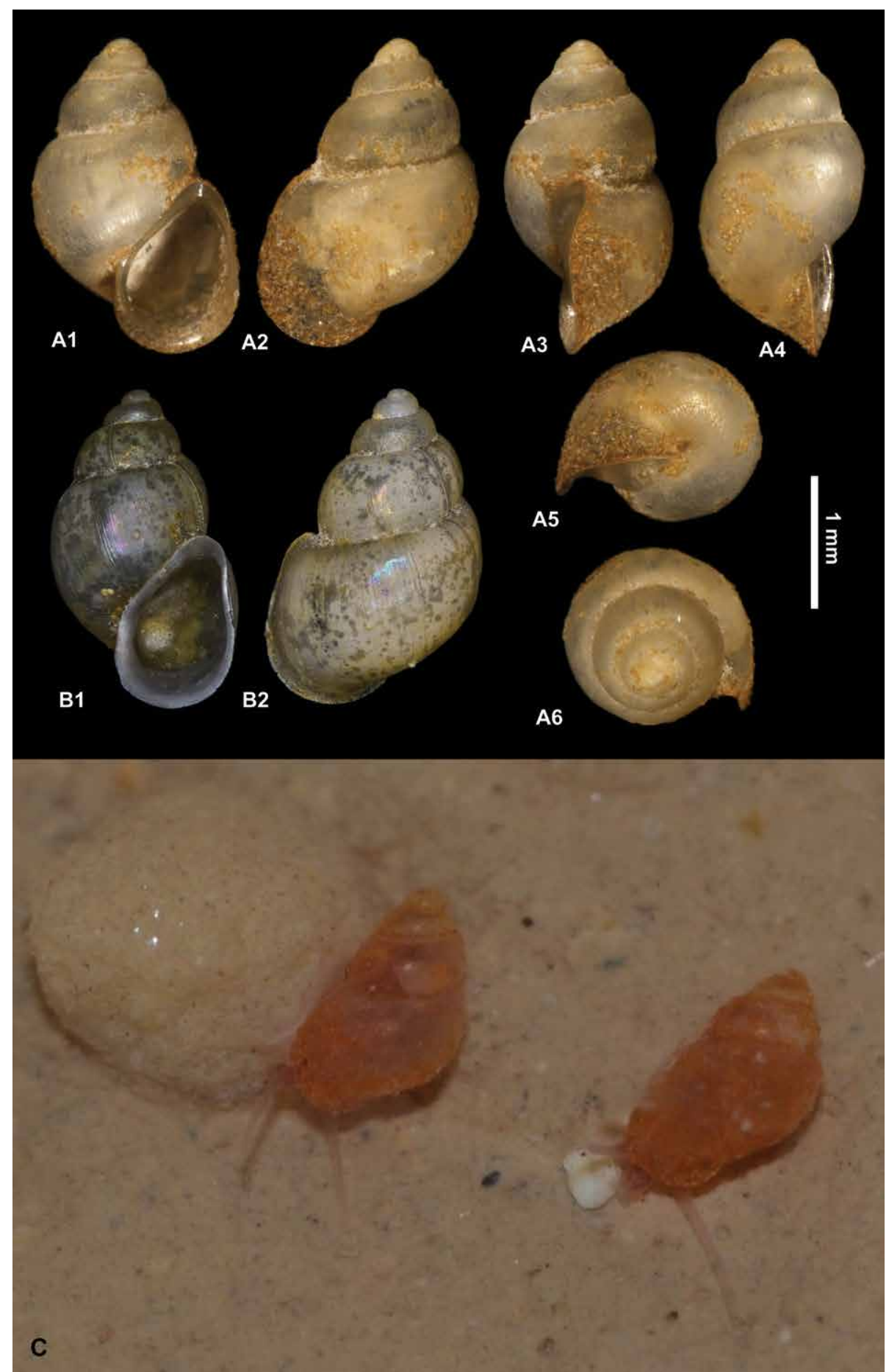

Figure 3. Trogloiranica tashanica n. sp., Iran, Khuzestan Province, Behbahan County, Tashan District, Sarjooshar Village, Tashan Cave. A1-A6: Holotype NMBE 558282; B1-B2: Paratype ZMUH 123; C: Live specimens of Trogloiranica tashanica n. sp., in their natural habitat within sulfide ponds of Tashan Cave (Specimens were transferred into a small stet basin at the pool shelf for photography) (photo: Jozef Grego, Yaser Fatemi and Mohammad Javad Malek-Hosseini). clear H3 (Fig. 7) clearly demonstrated that T. tashanica belongs to the Moitessieriidae (Bootstrap support 86\%). Likewise, the concatenated analysis supported this (Fig. 8).

\section{Etymology}

The species is named after the type locality, the Tashan Cave.

pear-shaped and slightly depressed form labral side, adapically separated from the body whorl by a weak furrow. Peristome margin expanded especially at its lower side and blunt along its outline. The labral lip characteristically sinuous in lateral view, columellar lip straight. Umbilicus closed and obscure.

\section{Anatomy}

Animal without eyes and pigment. Female reproductive organs (Fig. 4) typical of the Moitessieriidae: with rather big bursa copulatrix and one small receptaculum seminis (distal one (i.e., in the position of $\mathrm{rs}_{1}$ after Radoman 1983)). Penis (Fig. 5) simple, without any outgrowths. Loops of rectum (Fig. 5) with the faecal pellets arranged characteristically for the Moitessieriidae (Boeters \& Gittenberger 1990), like a bandolier, not a chain.

\section{Molecular phylogenetic relation- ships}

We present two original COI (cytochrome oxidase subunit I) (552 bp, GenBank Accession numbers MK906039-MK906040) and two histone 3 sequences (283 bp, GenBank Accession numbers MK906041MK906042). In both of these protein-coding loci the tests of Xia et al. (2003) revealed no saturation. Topology of the trees obtained with $\mathrm{BI}$ and $\mathrm{ML}$ analyses were identical. The obtained topologies using $\mathrm{BI}$ and $\mathrm{ML}$ were congruent. The phylogeny inferred with COI (Fig. 6) suggested a close relationship with the Moitessieriidae, but did not confirm the monophyly of the latter. Between the clade consisting of the Bythiospeum and the other grouping Iglica and Paladilhiopsis there were representatives of the family Cochliopidae, and T. tashanica between the Cochliopidae and Iglica/ Paladilhiopsis clade. However, the low bootstrap supports are typical of deep nodes inferred with COI. On the other hand, the phylogeny inferred with nu- 


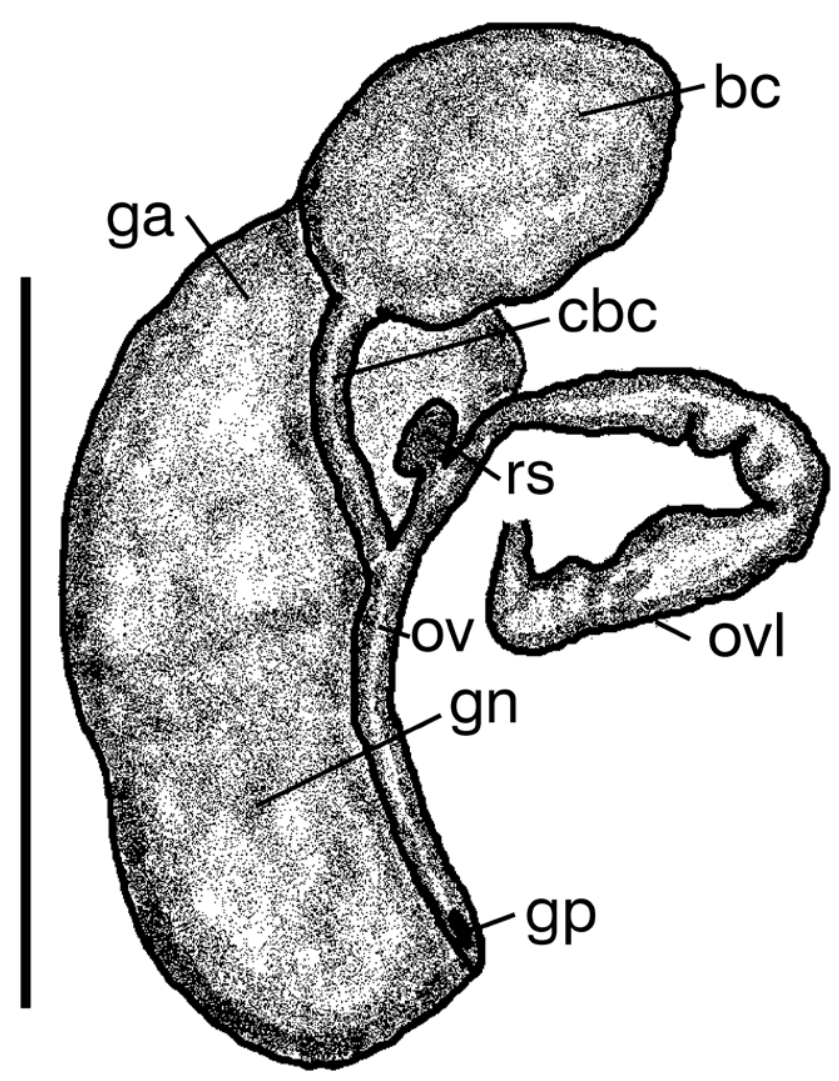

Figure 4. Renal and pallial part of the female reproductive organs of Trogloiranica tashanica n. sp. ((bc-bursa copulatrix, cbc-duct of bursa copulatrix, ga-albumen gland, gn-capsule gland, gp-gonopore, ov-oviduct, ovl-loop of oviduct, rs-seminal receptacle); bar equals $0.5 \mathrm{~mm}$.
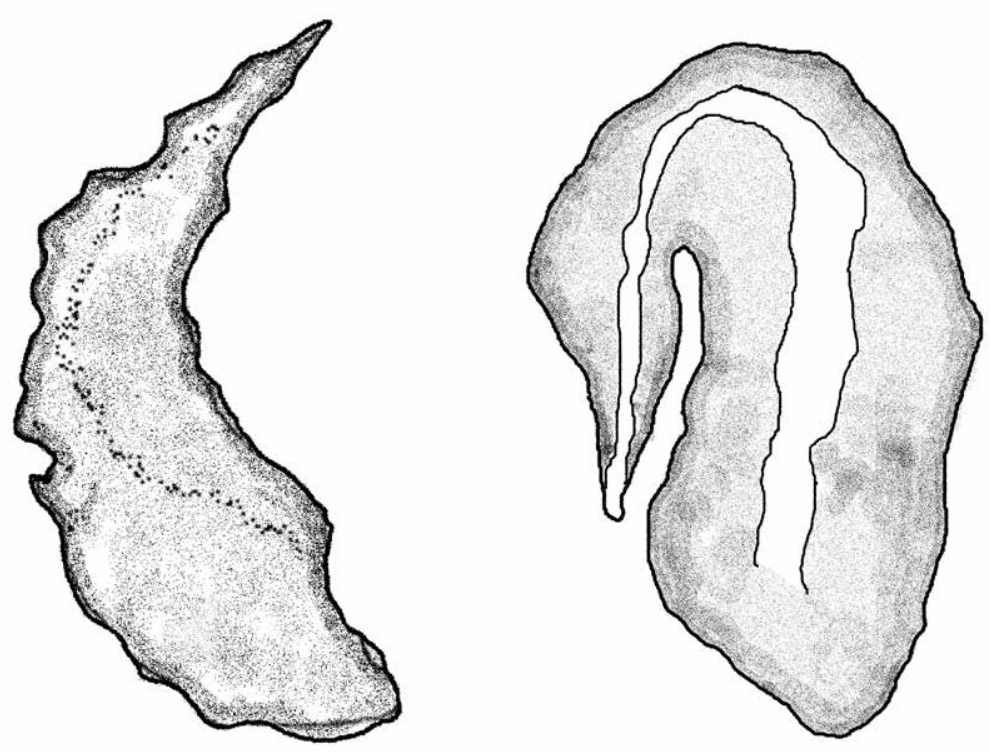

Figure 5. Trogloiranica tashanica n. sp., A. penis: at the left dorsally, in situ, in natural position, at the right ventrally, somewhat flattened, under the cover sleep. $B$. loops of the rectum, with the faecal pellets arranged characteristically for the Moitessieriidae, like a bandolier, not a chain.

gloiranica tashanica $\mathrm{n} . \mathrm{sp}$, is the first obligate cave-dwelling snail from Iran. The closest stygobiont gastropod records to this Iranian species can be found in the south-eastern part of Greater Caucasus in Georgia, in the vicinity of Sochi

\section{Distribution}

Known only from the type locality.

\section{Ecology}

Tashan Cave developed in Miocene limestones of Upper Red-Fars formation in the southeast part of the Zagros Mountain chain. The cave is situated under a semi-arid steppe plateau near the Sarjooshar village. The mostly horizontal cave with numerous passages and domes is several hundred meters long (detailed cave mapping is currently in progress). The morphology of the cave suggests a strong influence of sulfide-rich hydrothermal waters during the process of speleogenesis. Numerous pools and lakes inside the dark zone of the cave are rich in hydrogen sulfide, which is the main energy substrate for chemoautotrophic bacteria that utilize $\mathrm{CO}_{2}$ and methane as a carbon source (Palmer, 2007). Preliminary stable isotope data (Sarbu, personal communication) suggest that the microbial biofilms that thrive in the cave pools represent the main source of food for the rich cave fauna including the Trogloiranica tashanica n. sp., the blind fish Garra tashanensis Mousavi-Sabet, Vatandoust, Fatemi and Eagderi, 2016, and the isopod Stenasellus tashanicus Khalaji-Pirbalouty, Fatemi, Malek-Hosseini, Kuntner, 2018 that were recently described from this cave. Specimens of $T$. tashanica $\mathrm{n}$. sp. were found on the limestone walls, on the bottom rocks and on the mud covered by microbial biofilm in the cave pools. The water temperature was 25.4 ${ }^{\circ} \mathrm{C}$ and the $\mathrm{pH}$ was 7.8 . The atmospheric conditions in the cave are almost constant throughout the year at $25.2^{\circ} \mathrm{C}$ $-25.4{ }^{\circ} \mathrm{C}, 530 \mathrm{ppm}-755 \mathrm{ppm} \mathrm{\textrm {CO } _ { 2 }}$ saturation and $99.9 \%$ relative humidity.

\section{DISCUSSION}

Despite their ecological sensitivity and importance, subterranean ecosystems are very poorly studied worldwide and, except the areas of southern Europe, Balkans, southwestern Caucasus, eastern United States with northeast Mexico, Japan, Southeast Asia, New Zealand, and Tasmania, stygobiont gastropod records are extremely scarce (Bole and Velkovrh, 1986; Kabat and Hershler, 1993; Culver, 2012). This distribution represents only our present knowledge, while, most likely, the stygobiont Gastropoda inhabit all suitable habitats worldwide. The subterranean fauna of Iran is poorly known. Some cave-adapted groups of animals such as fishes (4 species), Crustacea (amphipods and isopods, more than 20 species), diplopods, and insects have been reported from Iran (Malek-Hosseini and Zamani, 2017). We suggest the putative presence of several groups of animals in hypogean environments of Iran, but a lot of field work is needed. Troof Iran, but a lot of field work is needed. Tro-
Iran. The closest stygobiont gastropod records 


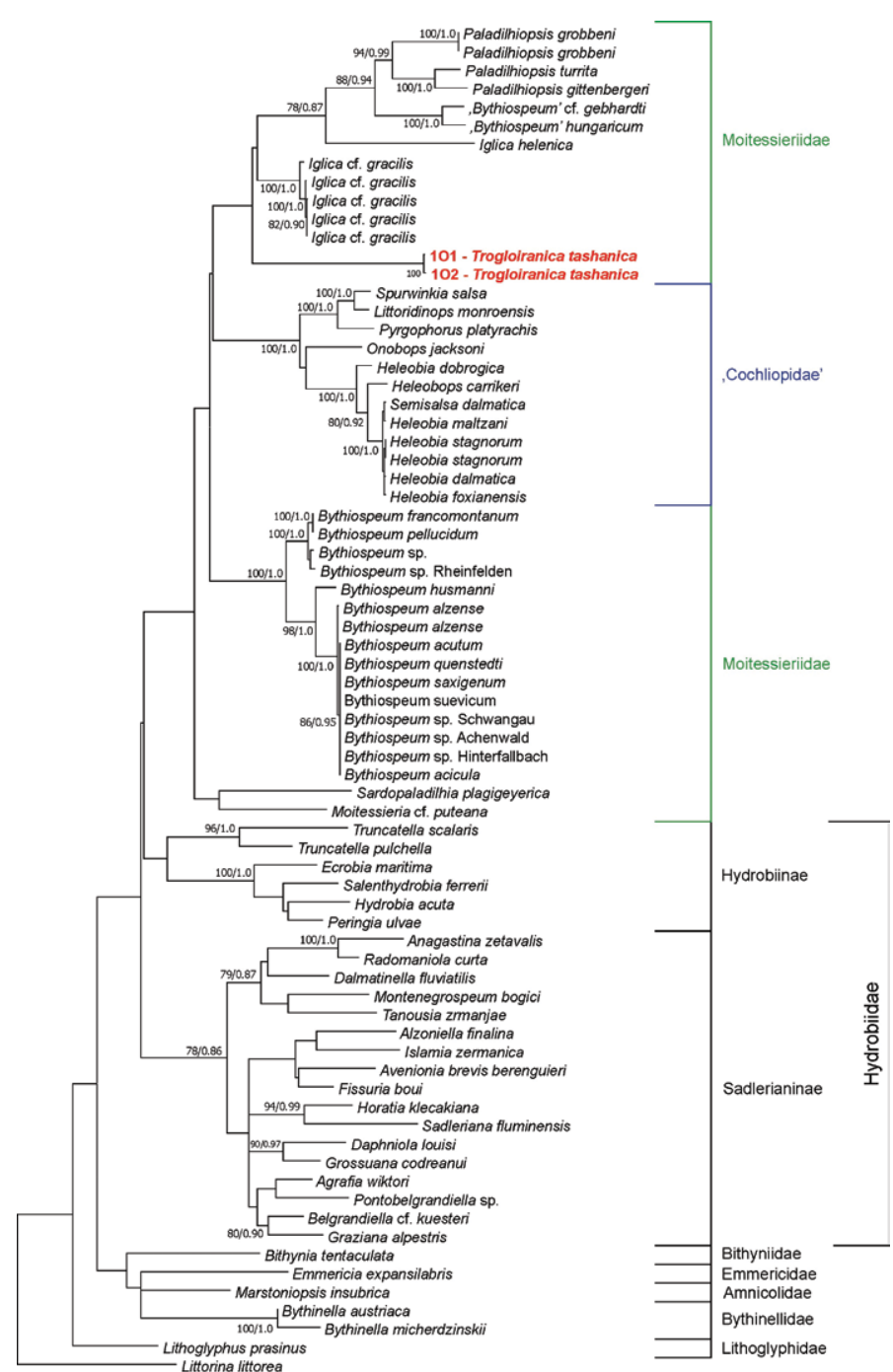

•

Figure 6. ML phylogeny based on COI. Bootstrap supports if $>70$ $\%$ and Bayesian probabilities given. New sequences of Trogloiranica tashanica are indicated in bold red; for the other sequences, see Table S1.

in Russia (Starobogatov, 1962; Vinarsky et al., 2014), and southern Turkmenistan (Zhadin, 1952), where we could expect the closest relations. The records from the Balkans (Glöer and Grego, 2015, Grego et al., 2017) in west and southeast Asia (Grego, 2018) towards the East, are likely not at all closely related to the Ponto-Caspian stygobionts, as it is proven for the related freshwater crenobionts of the family Hydrobiidae (Delicado et al., 2016). Of the five other known sulfide stygobiont gastropods, Heleobia dobrogica from Movile Cave represents the closest known lineage to $T$. tashanica n. sp. not only geographically, but also ecologically and by its three million-year old separation from its surface relatives (Falniowski et al., 2008). It appears that the other four known sulfidic stygobionts from the Frasassi caves in Italy, Lower Kane Cave in Wyoming, and Melissotrypa Cave in Greece could represent species with much younger adaptation history (Wethington and Guralnick, 2004). The communication of Islamia sulfurea with their surface relatives in the Frasassi caves (Bodon et al., 2009) is indicated by the distribution of the same species in other habitats and by the presence of the recent invader Potamopyrgus antipodarum Gray, 1843 at the same locality. This invasive species was found for the first time in Europe in 1889, and in Italy in 1961. Considering the special and rich biodiversity encountered in sulfidic caves and the estimation that $10 \%$ of the world's caves were formed by sulfidic speleogenesis (in some regions such as Greece these estimates reach up to $20 \%$ of the accessible caves (Vaxevanopoulos, 2009), we hypothesize that the sulfide-induced high subterranean diversity persisted in most of these ex-sulfidic caves after the input of hydrogen sulfide faded out. According to our experience, the ex-sulfidic cave Tahm Nam Dôn in Khammouane, Laos, hosted significantly higher stygobiontic gastropod diversity than any other neighboring cave without traces of the sulfide corrosion in its vicinity (Grego, 2018). If so, the importance 
of the sulfidic processes in the formation of the recent stygobiont diversity would be significantly strengthened, and the high subterranean diversity of many isolated subterranean environment could be better explained.

\section{CONCLUSIONS}

Tashan Cave likely represents another chemoautotrophically based cave ecosystem. The new species record is the sixth worldwide known stygobiont gastropod inhabiting subterranean sulfide-rich waters and the first records of stygobiont gastropod from Iran, indicating the large potential of the country for the presence of additional subterranean life forms. Although the whole ecosystem has not been well understood yet, at least we know that the water contains sulfide. The long natural history leads the subterranean ecosystems towards narrow, sometimes extreme sulfide specialization by ecological adaptation to the stable underground environment. Such a narrow specialization and long-term stable conditions reduced the adaptability of all the single ecosystem components and made it extremely sensitive against all, even very small changes, in the environmental conditions. The resulting very fragile web could be to some extent regarded as a multisymbiotic system. The disappearance of one component can lead to the collapse of the entire ecosystem. That is the main reason why the protection and conservation of such unique habitats as the Tashan Cave ecosystem have worldwide importance. Most of the caves worldwide hosting such rich sulfide ecosystems are heavily protected with restricted access, reduced to a small number of researchers per year. We believe the new locality also deserves such strict protection and that with the help of local environmentalists and cavers it can be soon achieved. Unfortunately, due to the negligence of authorities, cavers, locals, and even the research groups, a lot of habitat destruction has already occurred in this recently-discovered cave.

\section{ACKNOWLEDGEMENTS}

We thank to Anita Eschner and Nesrine Akkari from Vienna Natural History Museum for their help with microphotography. We are grateful to Mr. Barooninejad, the mayor of Sarjooshar Village and his family, Vahid Malek-Hosseini, Shahab Azizi, Saadat Rahideh, Meysam Abbasi, and Shirin Bahadoriniya for their assistance and hospitality during the field studies. Special thanks to Serban Sarbu, Bucharest, Romania, for his valuable comments during writing the manuscript and to Harry G. Lee, Jacksonville, Florida for proofreading the English. Molecular work was supported by the National Science Centre under Grant 2017/25/B/NZ8/01372 to Andrzej Falniowski.

\section{REFERENCES CITED}

Angyal D., Balázs G., Krízsik V., Herczeg G., and Fehér Z., 2018, Molecular and morphological divergence in a stygobiont gastropod lineage (Truncatelloidea, Moitessieriidae, Paladilhiopsis) within an isolated karstic area in the Mecsek Mountains (Hungary): Journal of Zoological Systematics and Evolutionary Research, v. 56, no. 4, p. 493-504, https://doi.org/10.1111/jzs.12220.

Arrozo, G., Arrozo, I., and Arrozo, E., 1997, Microbiological analysis of Maltravieso Cave (Caceres), Spain: International Biodeterioration and Biodegradation, v. 40, no. 2-4, p. 131-139, https://doi.org/10.1016/s0964-8305(97)00039-5.

Beran, L., Hofman, S., and Falniowski, A., 2015, Tanousia zrmanjae (Brusina, 1866) (Caenogastropoda: Truncatelloidea: Hydrobidae): A living fossil: Folia Malacologica, v. 23, p. 263-271, https://doi.org/10.12657/folmal.023.022.

Beran, L., Osikowski, A., Hofman, S., and Falniowski, A., 2016, Islamia zermanica (Radoman, 1973) (Caenogastropoda: Hydrobidae): morphological and molecular distinctness: Folia Malacologica, v. 24, p. 25-30, https://doi.org/10.12657/folmal.024.004.

Bodon, M., and Cianfaneli, S., 2012, II genere Islamia Radoman, 1973, nell'Italia centro-settentrionale (Gastropoda: Hydrobiidae): Bolletino Malacologico, v. 48, no. 1, p. 1-37.

Bodon, M., Cianfanelli, S. and Montanari, A., 2009, Mollusks of the Frasassi karstic complex and adjacent sulfidic spring: Abstracts with Program, The Frasassi Stygobionts and Their Sulfidic Environment, Genga, September 10-13, p. 9-11.

Boeters, H.D., and Gittenberger, E., 1990, Once more on the Moitessieriidae (Gastropoda Prosobranchia), with the description of Clameia brooki gen. et spec. nov.: Basteria, v. 54, p. 123-129.

Bole, J. and Velkovrh, F., 1986, Mollusca from continental subterranean aquatic habitats: in Botosaneanu P (ed.), Stygofauna Mundi, p. 177-208, Brill and Backhuys Publishers, Leiden.

Culver, D.C., 2012, Mollusks: in White, W.B., and Culver D.C. (eds.), Encyclopedia of Caves (Second Edition): New Yor, Academic Press, 512-517, https://doi.org/10.1016/B978-0-12-383832-2.00074-8.

Davis, G.M., Wilke, T., Spolsky, C., Qiu, C.-P., Qiu, D.-C., Xia, M.-Y., Zhang, Y., and Rosenberg, G., 1998, Cytochrome Oxidase I-based phylogenetic relationships among the Pomatiopsidae, Hydrobiidae, Rissoidae and Truncatellidae (Gastropoda: Caenogastropoda: Rissoacea), Malacologia, v. 40, p. 251-266.

Delicado, D., Pešić, V., and Glöer, P., 2016, Unraveling a new lineage of Hydrobiidae genera (Caenogastropoda: Truncatelloidea) from the Ponto-Caspian region. European Journal of Taxonomy, v. 208, p. 1-29, https://doi.org/10.5852/ejt.2016.208.

Deming, J., and Baros, J., 1993, Deep-sea smokers. Windows to a subsurface biosphere? Geochimica et Cosmochimica Acta, v. 57, p. 3219-3230, https://doi.org/10.1016/0016-7037(93)90535-5.

Edgar, R.C., 2004, MUSCLE: multiple sequence alignment with high accuracy and high throughput. Nucleic Acids Research, v. 32, p. 1792-1797, https://doi.org/10.1093/nar/gkh340.

Ektefa, Z., Ahmadi, E., and Shamohammadi, F., 2013, Identification. Snails of Dez River in Khuzestan Province and introduction two new records from Iran: Experimental Animal Biology, v. 2, no. 3, p. 51- 62 [In Persian].

Engel, A.S., 2012, Chemoautotrophy. in Encyclopedia of Caves (Second Edition). White, W.B., and Culver, D.C. (eds.): New York, Academic Press, p. 512-517, https://doi.org/10.1016/B978-0-12-383832-2.00074-8.

Engel, A.S., 2007, Observations on the biodiversity of sulfidic karst habitats. Journal of Cave and Karst Studies, v. 69, p. $187-206$.

Engel, A.S., Porter, M.L., Kinkle, B.K., and Kane, T.C., 2001, Ecological assessment and geological significance of microbial communities from Cesspool Cave, Virginia: Geomicrobiology Journal, v. 18, p. 259-274, https://doi.org/10.1080/01490450152467787. 
Engel, A.S., Stern, L.A., and Bennett, P.C., 2004, Microbial contributions to cave formation: New insights into sulfuric acid speleogenesis: Geology, v. 32; no. 5; p. 369-372, http://doi: 10.1130/G20288.1.

Falniowski, A., and Beran, L., 2015, Belgrandiella A. J. Wagner, 1928 (Caenogastropoda: Truncatelloidea: Hydrobiidae): how many endemic?:, Folia Malacologica, v. 23, p. 187-191, https://doi.org/10.12657/folmal.023.015.

Falniowski, A., Pešić, V., and Glöer, P., 2014, Montenegrospeum Pešić et Glöer, 2013: a representative of Moitessieriidae?: Folia Malacologica, v. 22, p. 263-268, https://doi.org/10.12657/folmal.022.023.

Falniowski, A., and Sarbu, S., 2015, Two new Truncatelloidea species from Melissotrypa Cave in Greece (Caenogastropoda), ZooKeys, v. 530, p. 1-14, https://doi.org/10.3897/zookeys.530.6137.

Falniowski, A., and Szarowska, M., 2012, Species distinctness of Lithoglyphus prasinus (Küster, 1852) (Rissooidea: Caenogastropoda): Folia Malacologica, v. 20, p. 99-104, https://doi.org/10.2478/v10125-012-0019-x.

Falniowski, A., and Szarowska, M., 2013, Phylogenetic relationships of Dalmatinella fluviatilis Radoman, 1973 (Caenogastropoda: Rissooidea): Folia Malacologica, v. 21, p. 1-7, https://doi.org/10.12657/folmal.021.001.

Falniowski, A., Szarowska, M., Glöer, P., and Pešić, V., 2012a, Molecules vs. morphology in the taxonomy of the Radomaniola/Grossuana group of Balkan Rissooidea (Mollusca: Caenogastropoda): Journal of Conchology, v. 41, p. 19-36.

Falniowski, A., Szarowska, M., Glöer, P., Pešić, V., Georgiev, D., Horsak, M., and Sirbu, I., 2012b, Radiation in Bythinella (Mollusca: Gastropoda: Rissooidea) in the Balkans: Folia Malacologica, v. 20, p. 1-9, https://doi.org/10.2478/v10125-012-0006-2.

Falniowski, A., Szarowska, M., Sirbiu, I., Hillebrand, A., and Baciu, M., 2008, Heleobia dobrogica (Grossu \& Negrea, 1989) (Gastropoda: Rissooidea: Cochliopidae) and the estimated time of its isolation in a continental analogue of hydrothermal vents: Molluscan Research, v. 28 , no. 3, p. 165-170.

Falniowski, A., and Wilke, T., 2001, The genus Marstoniopsis (Rissooidea: Gastropoda): intra- and intergeneric phylogenetic relationships: Journal of Molluscan Studies, v. 67, p. 483-488, https://doi.org/10.1093/mollus/67.4.483.

Glöer, P., and Grego, J., 2015, New subterranean freshwater Molluscs from Bosnia and Hercegovina (Mollusca: Hydrobiidae): Ecologica Montenegrina, v. 2, no. 4. p. 307-314.

Glöer, P., and Pešić, V., 2009, New freshwater gastropod species of Iran (Gastropoda: Stenothyridae, Bithyniidae, Hydrobiidae): Mollusca, v. 27, no. 1, p. 33-39.

Glöer, P., and Pešić, V., 2012, The freshwater snails (Gastropoda) of Iran, with descriptions of two new genera and eight new species: ZooKeys, v. 219, p. 11-61, https://doi.org/10.3897/zookeys.219.3406.

Grego, J., 2018, First record of subterranean rissoidean gastropod assemblages in Southeast Asia (Mollusca, Gastropoda, Pomatiopsidae): Subterranean Biology, v. 25, p. $9-34$, https://doi.org/10.3897/subtbiol.25.23463.

Grego, J., Glöer, P., Erőss, Z.P., and Fehér, Z., 2017a, Six new subterranean freshwater gastropod species from northern Albania and some new records from Albania and Kosovo (Mollusca, Gastropoda, Moitesieriidae and Hydrobiidae): Subterranean Biology, v. 23, p. 85-107, https://doi. org/10.3897/subtbiol.23.14930.

Grego, J., Gloer, P., Rysiewska, A., Hofman, S., and Falniowski, A., 2018, A new Montenegrospeum species from south Croatia (Mollusca: Gastropoda: Hydrobiidae): Folia Malacologica, v. 26, p. 25-34, https://doi.org/10.12657/folmal.026.004.

Grego, J., Hofman, S., Mumladze, L., and Falniowski, A., 2017b, Agrafia Szarowska et Falniowski, 2011 (Caenogastropoda: Hydrobiidae) in the Caucasus: Folia Malacologica, v. 25, p. 237-247, https://doi.org/10.12657/folmal.025.025.

Hall, T.A., 1999, BioEdit: a user-friendly biological sequence alignment editor and analysis program for Windows 95/98/N: Nucleic Acids Symposium Series, v. 41, p. 95-98.

Hershler, R., Winston, F., and Ponder, W.F., 1998, A review of Morphological Characters of Hydrobioid snails: Smithsonian Contributions to Zoology, v. 600, p. 1-55, https://doi.org/10.5479/si.00810282.600.

Hofman, S., Rysiewska, A., Osikowski, A., Grego, J., Sket, B., Prevorčnik, S., Zagmajster, M., and Falniowski, A., 2018, Phylogenetic relationships of the Balkan Moitessieriidae (Caenogastropoda: Truncatelloidea): Zootaxa, v. 4486:, p. 311-339, https://doi.org/10.11646/zootaxa.4486.3.5.

Holmes, A.J., Tujula, N.A., Holey, M., Contos, A., Hames, J.M., Rogers, P., and Gillings, M.R., 2001, Phylogenetic structure of unusual aquatic microbial formation in Nullarbor caves, Australia: Environmental Microbiology, v. 3, no. 4, p. 256-264, https://doi.org/10.1046/j.14622920.2001.00187.x.

Hose, L.D., Palmer, A.N., Palmer, M.V., Northup, D.E., Boston, P.J., and DuChene, H.R., 2000, Microbiology and geochemistry in a hydrogensulfide rich karst environment: Chemical Geology, v. 169, p. 399-423, https://doi.org/10.1016/s0009-2541(00)00217-5.

Hutchins, B., Engel, A., Nowlin, W., and Schwartz, B., 2016, Chemolithoautotrophy supports macroinvertebrate food webs and affects diversity and stability in groundwater communities: Ecology, v. 97, no. 6, p. 1530-1542, https://doi.org/10.1890/15-1129.1.

Jaume, D., Boxshal, G.A., and Humphreys, W.F., 2001, New stygobiont copepods (Calanoida; Misophrioida) from Bundera Sinkhole, an anchialine cenote in north-western Australia: Zoological Journal of the Linnean Society, v.133, p. 1-24, https://doi.org/10.1111/j.1096-3642.2001. tb00620.x.

Jones, D.S., Schaperdoth, I., and Macalady, J.L., 2014, Metagenomic evidence for sulfide oxidation in extremely acidic cave biofilms: Geomicrobiology Journal, v. 31, p. 194-204, https://doi.org/10.1080/01490451.2013.834008.

Kabat, A.R., and Hershler, R., 1993, The prosobranch snail family Hydrobiidae (Gastropoda: Rissooidea): review of classification and supraspecific taxa: Smithsonian Contributions to Zoology, v. 547, p. 1-94, https://doi.org/10.5479/si.00810282.547.

Kelley, J.L., Arias-Rodriguez, L., Martin, D.P., Muh-Ching, Yee, Bustamante, C.D., and Tobler, M., 2006, Mechanisms underlying adaptation to life in hydrogen sulfide-rich environments: Molecular Biology and Evolution, v. 33, no. 6, p. 1419-1434, https://doi.org/10.1093/molbev/ msw020.

Khalaji-Pirbalouty, V., Fatemi, Y., Malek-Hosseini, M.J., and Kuntner, M., 2018, A new species of Stenasellus Dollfus, 1897 from Iran, with a key to the western Asian species (Crustacea, Isopoda, Stenasellidae): ZooKeys, v. 766, p. 39-50, https://doi.org/10.3897/zookeys.766.23239.

Kroll, O., Hershler, R., Albrecht, C., Terrazas, E.M. Apaza, R., Fuentealba, C., Wolff C., and Wilke, T., 2012, The endemic gastropod fauna of Lake Titicaca: correlation between molecular evolution and hydrographic history: Ecology and Evolution, v. 2, p. 1517-1530, https://doi. org/10.1002/ece3.280.

Latella, L., Di Russo, C., De Pasquale, L., Dell'Anna, L., and Rampini, M., 1999, Ecological study in a new sulfurous cave from central Italy: in Holcer, D and Šašic M (eds.), Abstracts of the 14th International Symposium of Biospeleology, Makarska, Croatia September 19-26, 1999, Croatian Biospeleological Society, $54 \mathrm{p}$.

Layton, K.K., Martel, A.L., and Hebert, P.D., 2014, Patterns of DNA barcode variation in Canadian marine molluscs: PLoS ONE 9, E95003, https://doi.org/10.1371/journal.pone.0095003. 
Macalady, J.L., Jones, D.S., and Lyon, D.H., 2007, Extremely acidic, pendulous cave wall biofilms from the Frasassi cave system, Italy: Environmental Microbiology, v. 9, p. 1402-1414, https://doi.org/10.1111/j.1462-2920.2007.01256.x.

Malek-Hosseini, M.J., and Zamani, A., 2017, A checklist of subterranean arthropods of Iran: Subterranean Biology, v. 21 p. 19-46, https://doi. org/10.3897/subtbiol.21.10573.

Maltsev, V., and Korshunov, V., 1998, Geochemistry of fluorite and related features of the Kugitangtou Ridge Caves, Turkmenistan: Journal of Cave and Karst Studies, v. 60, no. 3, p. 151-155.

Mansoorian, A., 2001, Freshwater gastropod of Khuzestan Province, South-West Iran: Iranian International Journal of Science, v. 2, no. 2, p. 1-9.

Miller, M.A., Pfeiffer, W., and Schwartz, T., 2010, Creating the CIPRES Science Gateway for inference of large phylogenetic trees: Proceedings of the Gateway Computing Environments Workshop (GCE), November 14, New Orleans, LA, p. 1-8, https://doi.org/10.1109/ gce.2010.5676129.

Moghadam, A.S., and, Chegini, A.H., 2009, Parasitologic and ecological study on Melaniodes snails (Gastropoda) in Bandar Abbas district, Hormozgan, Iran: Hormozgan Medical Journal, v.,13, no. 1, p. 1-5 [In Persian].

Mowlavi, G., Mansoorian, A.B., Mahmoodi, M., Pourshojaei, R., and Salehi, M., 2009, Identification of freshwater snails in cane-sugar fields in the northern part of Khuzestan Province from a public health perspective: Journal of School of Public Health and Institute of Public Health Research, v. 7, no. 1, p. 69-76 [In Persian].

Mousavi-Sabet, H., Vatandoust, S., Fatemi, Y., and Eagderi, S., 2016, Tashan Cave a new cave fish locality for Iran; and Garra tashanensis, a new blind species from the Tigris River drainage: FishTaxa, v. 1, no. 3, p. 133-148.

Nouroozi, R.V., 2014, A survey of medically important snails of Gahar Lake in Lorestan Province, Iran: Journal of Medical Microbiology and Infectious Diseases, v. 2, no. 3, p. 91-94, https://doi.org/10.17795/ajcmi-30460.

Osikowski, A., Hofman, S., Rysiewska, A., Sket, B., Prevorčnik, S., and Falniowski, A., 2018, A case of biodiversity overestimation in the Balkan Belgrandiella A. J. Wagner, 1927 (Caenogastropoda: Hydrobiidae): molecular divergence not paralleled by high morphological variation: Journal of Natural History, v. 52, p. 323-344.

Palmer, A.N., 2007, Cave Geology. Cave Books, Dayton Ohio, p. 454.

Peterson, D.E., Finger, K.L., lepure, S., Mariani, S., Montanari, A., and Namiotko, T., 2013, Ostracod assemblages in the Frasassi Caves and adjacent sulfidic spring and Sentino River in the northeastern Apennines of Italy: Journa of Cave and Karst Studies, v. 75, p. 11-27, https://doi. org/10.4311/2011pa0230.

Por, F.D., 1963, The relict aquatic fauna of the Jordan Rift Valley: new contributions and review: Israel Journal of Zoology, v. 12, p. 47-58.

Por, F.D., 2007, Ophel: a groundwater biome based on chemoautotrophic resources. The global significance of the Ayalon cave finds, Israel: Hydrobiologia, v. 592, p. 1-10, https://doi.org/10.1007/s10750-007-0795-2.

Por, F.D., 2011, Groundwater life: some new biospeological views resulted from the Ophel paradigm: Travaux Institutul de Speologie Emile Racovitza, v. 50, p, 61-76.

Por, F.D., 2014, Sulfide Shrimp? Observations on the concealed life history of the Thermosbaenacea (Crustacea): Subterranean Biology, v. 14, p. 63-77, https://doi.org/10.3897/subtbiol.14.7927.

Porter, M.L., Engel, A.S., Kane, T.C., and Kinkle, B.K., 2009, Productivity-diversity relationships from chemolithoautotrophically based sulfidic karst systems: International Journal of Speleology, v. 38, no. 1, p. 27-40, https://doi.org/10.5038/1827-806x.38.1.4.

Porter, M.L, Russell, S., Engel, A.S., and Stern, L., 2002, Population studies of the endemic snail Physa spelunca (Gastropoda: Physidae) from Lower Kane Cave, Wyoming (abstract): Journal of Cave and Karst Studies, v. 64, p. 181.

Radoman, P., 1983, Hydrobioidea a superfamily of Prosobranchia (Gastropoda). I. Systematics: Monographs Serbian Academy of Sciences and Arts, DXLVII, Department Sciences, v. 57, p. 1-256.

Raeisi, E., and Laumanns, M., 2012, Cave Directory of Iran: 3rd edition, Berliner Hohlenkundiche berichte, v. 45-46.

Richling, I., Malkowsky, Y., Kuhn, Y., Niederhöfer, H.-J., and Boeters, H.D., 2016, A vanishing hotspot - impact of molecular insights on the diversity of Central European Bythiospeum Bourguignat, 1882 (Mollusca: Gastropoda: Truncatelloidea): Organisms Diversity \& Evolution, v. 17, p. 67-85, https://doi.org/10.1007/s13127-016-0298-y.

Riesch, R., Plath, M., and Schlupp, I., 2010, Toxic hydrogen sulfide and dark caves: life-history adaptations in a livebearing fish (Poecilia mexicana, Poeciliidae): Ecology, v. 91, no. 5, 1494-1505, https://doi.org/10.1890/09-1008.1.

Roach, K.R., Tobler, M.T., and Winemiller, K.O., 2011, Hydrogen sulfide, bacteria, and fish: a unique, subterranean food chain: Ecology, v. 92 , p. 2056-2062, https://doi.org/10.1890/11-0276.1.

Ronquist, F., Teslenko, M., van der Mark, P., Ayres, D., Darling, A., Hohna, S., Larget, B., Liu, L., Suchard, M.A., and Huelsenbeck, J.P., 2012, MrBayes 3.2: efficient Bayesian phylogenetic inference and model choice across a large model space: Systematic Biology, v. 61, p. 539-542, https://doi.org/10.1093/sysbio/sys029.

Rysiewska, A., Georgiev, D., Osikowski, A., Hofman, S., and Falniowski, A., 2016, Pontobelgrandiella Radoman, 1973 (Caenogastropoda: Hydrobiidae): A recent invader of subterranean waters?: Journal of Conchology, v. 42, p. 193-203, https://doi.org/10.1111/jzs.12159.

Rysiewska, A., Prevorčnik, S., Osikowski, A., Hofman, S., Beran, L., and Falniowski, A., 2017, Phylogenetic relationships in Kerkia and introgression between Hauffenia and Kerkia (Caenogastropoda: Hydrobiidae): Journal of Zoological Systematics and Evolutionary Research, v. 55, p. 106-117.

Sarbu, S.M., 2000, Movile cave: a chemoautotrophically based groundwater ecosystem: in Wilkens, H., Culver, D.C., and Humphreys, W.F, (eds.) Subterranean ecosystems: Amsterdam, Elsevier, p. 319-343.

Sarbu, S.M., Kane, T.C., and Kinkle, B.C., 1996, A chemoautothropically based cave ecosystem. Science, v. 272, p. 1953-1955, https://doi. org/10.1126/science.272.5270.1953.

Sarbu, S.M., and Popa, R., 1992, A unique Chemoautothrophically based cave ecosystem: in Camacho A. I. ed. The Natural History of Biospeleology, Madrid: Monografias Museo Nacional de Ciencias Naturales, p. 637-666 ISBN: 84-00-07280-4.

Schabereiter-Gurtner, C., Saiz-Jimenez, C., Piñar, G., Lubitz, W., and Rölleke, S., 2002, Phylogenetic 16S rRNA analysis reveals the presence of complex and partly unknown bacterial communities in Tito Bustillo cave, Spain, on its Palaeolithic paintings: Environmental Microbiology, v. 4, no. 7, p. 392-400, https://doi.org/10.1046/j.1462-2920.2002.00303.x.

Shahabuddin, M., Panezai, A., Nawaz, Y., and Iqbal, A., 2012, First record of fresh water snails Melanoides tuberculata from different regions of Balochistan province: Pakistan. Science International, v. 24, no. 1, p. 87-89.

Stamatakis, A., 2014, RAxML version 8: a tool for phylogenetic analysis and post-analysis of large phylogenies: Bioinformatics, v. 30 , p. 1312-1313, https://doi.org/10.1093/bioinformatics/btu033. 
Starobogatov, Y.I., 1962, Contribution to molluscs from subterranean waters of Caucasus: Bulletin of Moscow Society of Naturalists - Biological series, v. 67 , no. 6 , p. $42-54$.

Szarowska, M., 2006, Molecular phylogeny, systematics and morphological character evolution in the Balkan Rissooidea (Caenogastropoda): Folia Malacologica, v. 14,p. 99-168, https://doi.org/10.12657/folmal.014.014.

Szarowska, M., and Falniowski, A., 2011, An unusual, flagellum-bearing hydrobiid snail (Gastropoda: Rissooidea: Hydrobiidae) from Greece, with descriptions of a new genus and a new species: Journal of Natural History, v. 45, p. 2231-2246, https://doi.org/10.1080/00222933.2011.591067.

Szarowska, M., and Falniowski, A., 2013a, Phylogenetic relationships of the Emmericiidae (Caenogastropoda: Rissooidea): Folia Malacologica, v. 21, p. 67-72, https://doi.org/10.12657/folmal.021.007.

Szarowska, M., and Falniowski, A., 2013b, Species distinctness of Sadleriana robici (Clessin, 1890) (Gastropoda: Rissooidea): Folia Malacologica, v. 21, p. 127-133, https://doi.org/10.12657/folmal.021.016

Szarowska, M., and Falniowski, A., 2014a, Horatia Bourguignat, 1887: is this genus really phylogenetically very close to Radomaniola Szarowska, 2006 (Caenogastropoda: Rissooidea): Folia Malacologica, v. 22, p. 31-39, https://doi.org/10.12657/folmal.022.003.

Szarowska, M., and Falniowski, A., 2014b, Ventrosia maritima (Milaschewitsh, 1916) and V. ventrosa (Montagu, 1803) in Greece: molecular data as a source of information about species ranges within the Hydrobiinae (Caenogastropoda: truncatelloidea): Folia Malacologica, v. 22, p. 61-67, https://doi.org/10.12657/folmal.022.006.

Szarowska, M., Grzmil, P., Falniowski, A., and Sirbu, I., 2007, Grossuana codreanui (Grossu, 1946) and the phylogenetic relationships of the East Balkan genus Grossuana (Radoman, 1973) (Gastropoda: Rissooidea:, Hydrobiologia, v. 579, p. 379-391, https://doi.org/10.1007/s10750-006-0530-4.

Szarowska, M., Hofman, S., Osikowski, A., and Falniowski, A., 2014a, Daphniola Radoman, 1973 (Caenogastropoda: Truncatelloidea) at east Aegean islands: Folia Malacologica, v. 22, p. 269-275, https://doi.org/10.12657/folmal.022.021.

Szarowska, M., Hofman, S., Osikowski, A., and Falniowski, A., 2014b, Heleobia maltzani (Westerlund, 1886) (Caenogastropoda: Truncatelloidea: Cochliopidae) from Crete and species-level diversity of Heleobia Stimpson, 1865 in Europe: Journal of Natural History, v. 48, p. 2487-2500, https://doi.org/10.1080/00222933.2014.946109.

Szarowska, M., Osikowski, A., Hofman, S., and Falniowski, A., 2016, Pseudamnicola Paulucci, 1878 (Caenogastropoda: Truncatelloidea) from the Aegean Islands: a long or short story?: Organisms Diversity and Evolution, v. 16, p. 121 -139, http://doi.org/10.1007/s13127-015-0235-5.

Tamura, K., Peterson, D., Peterson, N., Stecher, G., Nei, M., and Kumar, S., 2013, MEGA5: Molecular evolutionary genetics analysis using maximum likelihood, evolutionary distance, and maximum parsimony method: Molecular Biology and Evolution, v. 28, p. 2731-2739, https://doi. org/10.1093/molbev/msr121.

Tobler, M., Roach, K., Winemiller, K.O., Morehouse, R.L., and Plath, M., 2013, Population structure, habitat use, and diet of giant waterbugs in a sulfidic cave: The Southwestern Naturalist, v. 58, no. 4, p. 420-426, https://doi.org/10.1894/0038-4909-58.4.420.

Vaxevanopoulos, M., 2009, Identifying hypogenic features in Greek Caves: 15th International Congress of Speleology Proceedings, Earth Sciences, v. 1, p. 1713-1716.

Vinarski, M.V., Palatov, D.M., and Glöer, P., 2014, Revision of 'Horatia' snails (Mollusca: Gastropoda: Hydrobiidae sensu lato) from South Caucasus with description of two new genera: Journal of Natural History, v. 48, p. 37-38, 2237-2253, https://doi.org/10.1080/00222933.2014.91721 0.

Wethington, A., and Guralnick, R., 2004, Are populations of physids from different hot springs distinctive lineages?: American Malacological Bulletin, v. 191, no. 2, p. 135-144.

Wilke, T., 2003, Salenthydrobia gen. nov. (Rissooidea: Hydrobiidae): a potential relict of the Messinian Salinity Crisis: Zoologica Journal of the Linnean Society, v. 137, p. 319-336, https://doi.org/10.1046/j.1096-3642.2003.00049.x.

Wilke, T., and Davis, G. M., 2000, Infraspecific mitochondrial sequence diversity in Hydrobia ulvae and Hydrobia ventrosa (Hydrobiidae: Rissoacea: Gastropoda): Do their different life histories affect biogeographic patterns and gene flow?: Biological Journal of the Linnean Society, v. 70, p. 89-105, https://doi.org/10.1006/bijl.1999.0388.

Wilke, T., Davis, G.M., Falniowski, A., Giusti, F., Bodon, M., and Szarowska, M., 2001, Molecular systematics of Hydrobiidae (Mollusca: Gastropoda: Rissooidea): testing monophyly and phylogenetic relationships: Proceedings of the Academy of Natural Sciences of Philadelphia, v. 151 , p. 1-21, https://doi.org/10.1635/0097-3157(2001)151[0001:MSOHMG]2.0.CO;2.

Wilke, T., Haase, M., Hershler, R., Liu, H.P., Misof, B., and Ponder, W., 2013, Pushing short DNA fragments to the limit: Phylogenetic relationships of 'hydrobioid' gastropods (Caenogastropoda: Rissooidea): Molecular Phylogenetics and Evolution, v. 66, p. 715-736, https://doi. org/10.1016/j.ympev.2012.10.025,

Wilke, T., Rolán, E., and Davis, G.M., 2000, The mudsnail genus Hydrobia s.s. in the northern Atlantic and western Mediterranean: a phylogenetic hypothesis: Marine Biology, v. 137, p. 827-833, https://doi.org/10.1007/s002270000407.

Xia, X., 2013, DAMBE: A comprehensive software package for data analysis in molecular biology and evolution: Molecular Biology and Evolution, v. 30, p. 1720-1728, https://doi.org/10.1093/molbev/mst064.

Xia, X., 2000, Data Analysis in Molecular Biology and Evolution: Kluwer Academic Publishers, Boston, Dordrecht \& London, p. XVI, 280, https:// doi.org/10.1007/b113439.

Xia, X., Xie, Z., Salemi, M., Chen, L., and Wang, Y., 2003, An index of substitution saturation and its application: Molecular Phylogenetic and Evolution, v. 26, p. 1-7, https://doi.org/10.1016/s1055-7903(02)00326-3.

Zhadin, V.I., 1952, Mollusks of Fresh and Brackish Waters of the U.S.S.R.: Academie of Sciences of the Union of Soviet Socialist Republics (translated by the Israel Program of Scientific Translations, Jerusalem 1965), xvi + $368 \mathrm{p}$. 